\title{
A new species of Utiaritichthys Miranda Ribeiro (Characiformes: Serrasalmidae) from the Serra dos Parecis, Tapajós drainage
}

\author{
Thiago N. A. Pereira and Ricardo M. C. Castro
}

Utiaritichthys esguiceroi is described from the upper portion of the rio Juruena, rio Tapajós drainage, Mato Grosso State, Central Brazil. The new species distinguished from its two congeners, $U$. sennaebragai Miranda Ribeiro and $U$. longidorsalis Jégu, Tito de Morais \& Santos, by having 99 to 101 perforated scales on lateral line (vs. 69 to 83), presence of 17 to 19 prepelvic spines (vs. 9-13 in U. sennaebragai and 28-31 in U. longidorsalis), 20 to 21 postpelvic spines (vs. 15 to 19 in U. sennaebragai, and 14 in U. longidorsalis), and 23 to 25 circumpeduncular scales (vs. 30-48 in U. sennaebragai, and 33-35 in U. longidorsalis). Furthermore, the new species differs from $U$. longidorsalis by having larger interdorsal width, and adipose-fin base length (11.8-15.6 vs. 7.1-7.9\% of SL, and 4.2-5.8 vs. 3.7-3.8\% of SL, respectively).

Utiaritichthys esguiceroi é descrita da porção superior do rio Juruena, bacia do rio Tapajós, estado do Mato Grosso, Brasil Central. A espécie nova diferencia-se de suas congêneres, U. sennaebragai Miranda Ribeiro e U. longidorsalis Jégu, Tito de Morais \& Santos, pela presença de 99 a 101 escamas perfuradas na linha lateral (vs. 69 a 83), presença de 17 a 19 espinhos prépélvicos (vs. 9-13 em U. sennaebragai e 28-31 em U. longidorsalis), 20 a 21 espinhos pós-pélvicos (vs. 15 a 19 em U. sennaebragai e 14 em U. longidorsalis), e 23-25 escamas da série circumpeduncular (vs. 30-48 em U. sennaebragai e 33-35 em U. longidorsalis). Em adição, a espécie nova difere de $U$. longidorsalis por possuir a largura interdosal e comprimento da base da nadadeira adiposa maiores (11,8-15,6 vs. 7,1-7,9\% do CP e 4,2-5,8 vs. 3,7-3,8\% do CP, respectivamente).

Key words: Neotropical fish, Pacú borracha, Systematics, Taxonomy, Upper Juruena basin.

\section{Introduction}

The family Serrasalmidae contains 16 genera and approximately 87 valid recent species, and one fossil species of (Megapiranha paranensis Cione, Dahdul, Lundberg \& Machado-Allison) widely distributed throughout Neotropical drainages, mostly in South America (Jégu, 2003; Jégu et al., 2004; Cione et al., 2009; Hubert \& Reno, 2010; Andrade et al., 2013; Eschmeyer \& Fong, 2014).

The real taxonomic level of the group remains unsolved. Machado-Allison $(1983,1986)$ proposed the monophyly of the serrasalmids, based on 27 morphological characters. Subsequently, in molecular phylogenies, Orti et al. (1996) and Calcagnotto et al. (2005) corroborated the monophyly of the group. Calcagnotto et al. (2005) based on their molecular tree, raised the group to the family level, disagreeing with Machado-Allison (1982, 1983, 1985, 1986) and Jégu (2003), that considered the clade in question as a subfamily of Characidae.

Utiaritichthys sennaebragai was described by Miranda Ribeiro (1937) from the rio Papagaio, rio Tapajós drainage, upriver from Salto de Utiariti (waterfall), Mato Grosso State, Central Brazil. Jégu et al. (1992) redescribed the genus and described an additional species, $U$. longidorsalis, from the rio Aripuanã, rio Madeira drainage, also in Central Brazil. Utiaritichthys sennaebragai is recorded in the rios Tapajós, Xingu, Tocantins-Araguaia and Trombetas, in the Amazon drainage, and also in the río Orinoco, in Venezuela; and $U$. longidorsalis Jégu, Tito de Moraes \& Santos, 1992, is known only from the rio Madeira. A new species of Utiaritichthys was discovered during recent collections made in the rio Juruena, rio Tapajós drainage, in the region of the Chapada dos Parecis, Mato Grosso State, Brazil, and it is described herein.

Laboratório de Ictiologia de Ribeirão Preto (LIRP), Departamento de Biologia da Faculdade de Filosofia, Ciências e Letras, Universidade de São Paulo. Avenida dos Bandeirantes, 3900, 14040-901 Ribeirão Preto, SP, Brazil. thiago.nilton@gmail.com (corresponding author), rmccastro@ffclrp.usp.br (RMCC) 


\section{Material and Methods}

The counts and measurements followed Jégu et al. (1992). Measurements were taken point to point with the aid of calipers on the left side of the specimens, whenever possible. All measurements are expressed as percentages of standard length (SL), except for subunits of the head, which are expressed as percentages of the head length (HL). Vertebrae counts were made based mostly on $69 \mathrm{X}$-rayed specimens and two cleared and stained (c\&s) specimens prepared according to Taylor \& Van Dyke (1985). Skeletal meristic data, numbers of supraneurals, gill-rakers in the first gill arch, teeth, and procurrent caudal-fin rays, were also taken from cleared and stained material. Examined specimens are deposited in the ichthyological collection of the Laboratório de Ictiologia de Ribeirão Preto, Faculdade de Filosofia, Ciência e Letras da Universidade de São Paulo; Ribeirão Preto (LIRP); Museu de Zoologia da Universidade de São Paulo, São Paulo (MZUSP), and Museu de Ciências e Tecnologia da Pontifícia Universidade Católica do Rio Grande do Sul, Porto Alegre (MCP). Asterisk indicates holotype data and numbers in parentheses indicate data from paratypes plus non-types specimens examined. All the non-type material listed in the description was formerly utilized in an independent study of stomach content analysis and sexual determination, having had their visceral cavities evacuated and general body shape and proportions distorted, as a result.

\section{Utiaritichthys esguiceroi, new species}

Figs. 1-2

Holotype. LIRP 8184, 197.9 mm SL, Brazil, Mato Grosso State, rio Tapajós drainage, rio Juruena, nearby the município de Sapezal, 1251’29"S 5855’23"W, 03 Nov 2008, , R. J. Ilário, M. S. F. Arcifa \& A. L. H. Esguícero.

Paratypes. LIRP 8185, 11 (2 c\&s), 187.0-260.0 mm SL. MCP 46331, 3, 197.0-217.0 mm SL. MZUSP 109232, 3, 192.0-196.0 mm SL, same data as holotype.

Non-type material examined. Brazil, Mato Grosso State, município de Sapezal, rio Juruena, LIRP 8187, 15, 174.0-211.0 mm SL; LIRP 8188, 3, 187.0-192.0 mm SL, same locality as holotype. LIRP 9045, 13, 21.0-62.0 mm SL, PCH Cidezal, 13²2’39"S 5900’57"W, 18 Mar 2008, R. J. Ilário. LIRP 9046, 10, 24.0-43.0 mm SL, PCH Parecis, 1304'43"S 5858'06"W, 19 Mar 2008, R. J. Ilário. LIRP 9047, 13, 105.4-262.0 mm SL, PCH Sapezal, 13¹6’10"S 5901’26"W, 18 Mar 2008, R. J. Ilário. LIRP 9048, 14, 110.4-180.5 mm SL, PCH Parecis, 1304’43"S 5858’06"W, 19 Mar 2008, R. J. Ilário.

Diagnosis. Utiaritichthys esguiceroi differs from its congeners by the higher number of perforated scales on the lateral line (99-101, vs. 69-72 in U. sennaebragai, and 78-82 in $U$. longidorsalis), the higher number of prepelvic spines (17-19, vs. 9-10 in U. sennaebragai, and 28-31 in U. longidorsalis), the lower number of postpelvic spines (20-21, vs. 15-17 in $U$. sennaebragai, and 14 in $U$. longidorsalis), and also by the number of circumpeduncular scales (23-25 vs. 30-48 in $U$. sennaebragai, and 33-35 in U. longidorsalis). Furthermore, the new species differs from $U$. longidorsalis by having larger interdorsal width (11.8-15.6 vs. 7.1-7.9\% of SL), and larger adipose-fin base length (4.2-5.8 vs. 3.7-3.8\% of SL).

\section{Description}

Morphometric data presented in Table 1 . Body deeply compressed, with rounded dorsal and ventral profiles. Greatest body depth at dorsal fin origin. Dorsal profile of head distinctly rounded from upper lip to vertical through anterior nostrils, convex from latter point to tip of supraoccipital spine. Predorsal profile slightly convex from tip of supraoccipital spine to dorsal-fin origin; posteroventrally inclined along dorsal-fin base; slightly convex from posterior dorsal-fin base to adipose-fin origin and very slightly concave along caudal peduncle. Anterior portion of ventral profile of head almost straight and posteroventrally inclined; posterior portion of head and body convex, strongly inclined posterodorsally along anal-fin base and slightly concave along caudal peduncle.

Series of inconspicuous spines forming subtle ventral keel extending approximately from vertical line crossing middle length of first pectoral-fin ray to anus. Total number of ventral spines 38 (8 + 21 non-type specimens) or 40* $(10+30$ nontype specimens); prepelvic spines $17(7+21$ non-type specimens) or 19* (11 + 30 non-type specimens); postpelvic spines $20 *$ (12 + 21 non-type specimens) or 21 (6 + 30 nontype specimens). First prepelvic spine trapezoidal in ventral view; the remaining pelvic spines triangular with a spine-like posteriorly-oriented projection; length of posterior spine like projection shorter than plate base width. Postpelvic spines with spine-like projections longer than prepelvic spines and bifurcated posteriorly.

Mouth terminal, with spatulate teeth. Maxilla toothless. Posterior portion of maxilla wider than anterior. Premaxilla with two rows of teeth: labial row with three teeth; first two teeth tricuspid and third truncated: lingual row with four slightly incisform teeth, all with base wider than crown. Dentary teeth five: first four teeth tricuspid, and last tooth truncated: teeth decreasing gradually in size in outer tooth row and a single blunt conical, symphyseal tooth on inner row (Fig. 2): gill-rakers 12/1/18* (holotype + 2 c\&s).

Dorsal-fin rays ii, $21 *(18+51$ non-type specimens); first unbranched ray approximately half the length of second ray. Dorsal-fin origin preceded by forwardly directed blunt pterygiophore spine. Dorsal-fin origin located approximately at the middle of SL, at vertical through pelvic-fin origin. Dorsal-fin pterygiophores $19 *(16+51$ non-type specimens). Analfin rays iii-iv, 30 ( $9+15$ non-type specimens) or $32 *(9+36$ non-type specimens): anal fin sexually dimorphic (see under Sexual dimorphism). Anal-fin origin located distinctly anterior to vertical through dorsal-fin terminus. Anal-fin pterygiophores $33 *(18+51$ non-type specimens). Short well-developed adipose fin present, origin equidistant to dorsal-fin terminus and caudal-fin origin and, anteriorly to vertical through middle of 


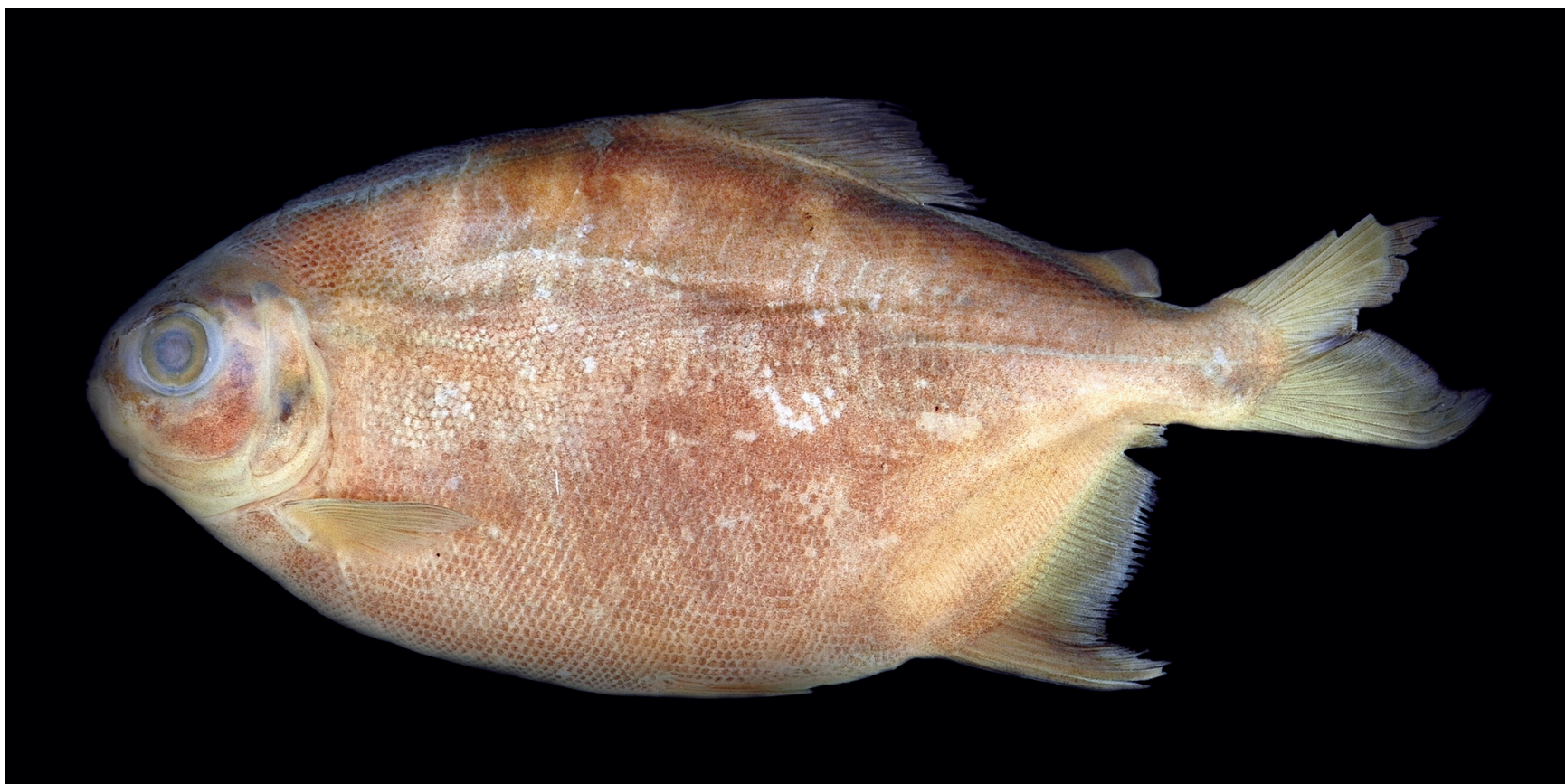

Fig. 1. Utiaritichthys esguiceroi, holotype, female, LIRP 8184, 197.9 mm SL, rio Juruena, rio Tapajós drainage, município de Sapezal, Mato Grosso State, Brazil.

anal-fin. Pectoral-fin rays i,16* (18 + 51 non-type specimens), distal margin slightly convex; its tip not reaching vertical through dorsal and pelvic-fin origins. Pelvic-fin rays i, $7 *(18+$ 51 non-type specimens). Caudal fin strongly furcate, both lobes equal in size. Principal caudal-fin rays i,9/i,8* (18 + 51 non-type specimens); ten and nine dorsal and ventral caudal-fin procurrent rays, respectively. Vertebrae $35 *(18+51$ non-type specimens). Precaudal vertebrae $19 *(18+51$ non-type specimens); caudal vertebrae 16 (18 +51 non-type specimens). Supraneurals $8 *(18+51$ non-type specimens).

Scales cycloid, small. Lateral line complete; perforated scales $99 *(13+38$ non-type specimens) or 101 ( $5+13$ nontype specimens). Longitudinal scale rows between dorsal-fin origin and lateral line $34 *(11+35$ non-type specimens $)$ or 36 ( $7+16$ non-type specimens); scale rows between lateral line to pelvic-fin origin $27\left(4+8\right.$ non-type specimens) or $28^{*}(14+$ 43 non-type specimens). Circumpeduncular scales 23 ( $4+2$ non-type specimens), $24 *(12+42$ non-type specimens) or $25(2+7$ non-type specimens $)$. Vertebrae $35 *(18+51$ nontype specimens).

Color in alcohol. Overall body background color light brown. Dorsal portion of head and predorsal region dark brown. Dark brown patches on first to fourth and sixth infraorbitals. Yellow pale background on fifth infraorbital. Dark vertically elongated spot on posterior portion of opercle. A single, very inconspicuous humeral blotch. Flanks with a dark brown narrow stripe extending from posterior border of opercle to caudal fin. Five to six large vertical bands along dorsal portion of flank; first through third more conspicuous. Ventral portion of body pale yellow and white. Dorsal and anal fins hyaline with ray tips with dark chromatophores. Yellowish white pectoral fin rays, becoming hyaline toward tips; yellowish white pelvic-fin rays. Yellowish white caudal-fin rays, with mostly brown tips.

Table 1. Morphometric data for Utiaritichthys esguiceroi. Range, Mean and Standard Deviation (SD) include values of the holotype $(\mathrm{H}) ; \mathrm{n}=$ number of specimens.

\begin{tabular}{|c|c|c|c|c|c|}
\hline Character & $\mathrm{H}$ & $\mathrm{n}$ & Range & Mean & SD \\
\hline Standard length & 197.9 & 18 & $178.1-228.3$ & 197.7 & - \\
\hline \multicolumn{6}{|c|}{ Percents of Standard Length (SL) } \\
\hline Greatest body depth & 51.3 & 18 & $45.2-51.6$ & 49.7 & 1.9 \\
\hline Head height & 35.4 & 18 & 25.8-35.3 & 29.7 & 2.1 \\
\hline Head length & 25.4 & 18 & 24.3-28.0 & 26.1 & 1.0 \\
\hline Dorsal fin base length & 23.5 & 18 & 21.3-26.0 & 23.5 & 1.4 \\
\hline Dorsal fin length & 24.8 & 18 & $19.4-29.0$ & 22.3 & 2.0 \\
\hline Interdorsal width & 13.6 & 18 & $11.8-15.6$ & 14.4 & 0.9 \\
\hline Anal fin base length & 26.1 & 18 & 24.1-28.4 & 25.8 & 1.1 \\
\hline Adipose fin base length & 5.0 & 18 & $4.2-5.8$ & 4.8 & 0.4 \\
\hline Pectoral fin length & 20.5 & 18 & $18.0-20.6$ & 19.4 & 0.8 \\
\hline Predorsal length & 56.7 & 18 & 51.5-58.1 & 55.5 & 2.0 \\
\hline Preanal length & 79.3 & 18 & $72.9-86.0$ & 78.4 & 2.6 \\
\hline Prepectoral length & 24.5 & 18 & $23.5-27.3$ & 25.0 & 1.0 \\
\hline Prepelvic length & 55.8 & 18 & $55.8-61.9$ & 58.7 & 1.7 \\
\hline Pelvic/anal distance & 10.5 & 18 & $8.0-10-5$ & 9.0 & 0.6 \\
\hline Pelvic/pectoral distance & 18.5 & 18 & $17.0-19.9$ & 18.6 & 0.8 \\
\hline Caudal peduncle depth & 9.7 & 18 & 8.4-9.7 & 9.1 & 0.3 \\
\hline Caudal peduncle length & 7.9 & 18 & $6.1-9.6$ & 7.7 & 1.0 \\
\hline \multicolumn{6}{|c|}{ Percents of Head Length (HL) } \\
\hline Eye diameter & 27.8 & 18 & $21.5-27.8$ & 24.7 & 1.4 \\
\hline Interorbital width & 43.3 & 18 & $37.7-43.3$ & 40.6 & 1.5 \\
\hline $3^{\text {rd }}$ infraorbital width & 13.2 & 18 & $9.9-14.5$ & 13.0 & 1.1 \\
\hline $4^{\text {th }}$ infraorbital width & 15.1 & 18 & $12.0-17.8$ & 15.1 & 1.1 \\
\hline Check gap width & 14.2 & 18 & $9.7-14.2$ & 11.7 & 1.1 \\
\hline Snout length & 31.5 & 18 & 28.6-34.9 & 32.8 & 1.8 \\
\hline Postorbital distance & 41.6 & 18 & 39.1-46.9 & 43.0 & 1.9 \\
\hline \multicolumn{6}{|c|}{ Percents of dorsal fin base length } \\
\hline Interdors & 58.1 & 18 & 53.3-65.6 & 60.0 & 3.2 \\
\hline Adipose fin base l & 21.3 & 18 & $17.2-26.5$ & 19.9 & 2.1 \\
\hline
\end{tabular}




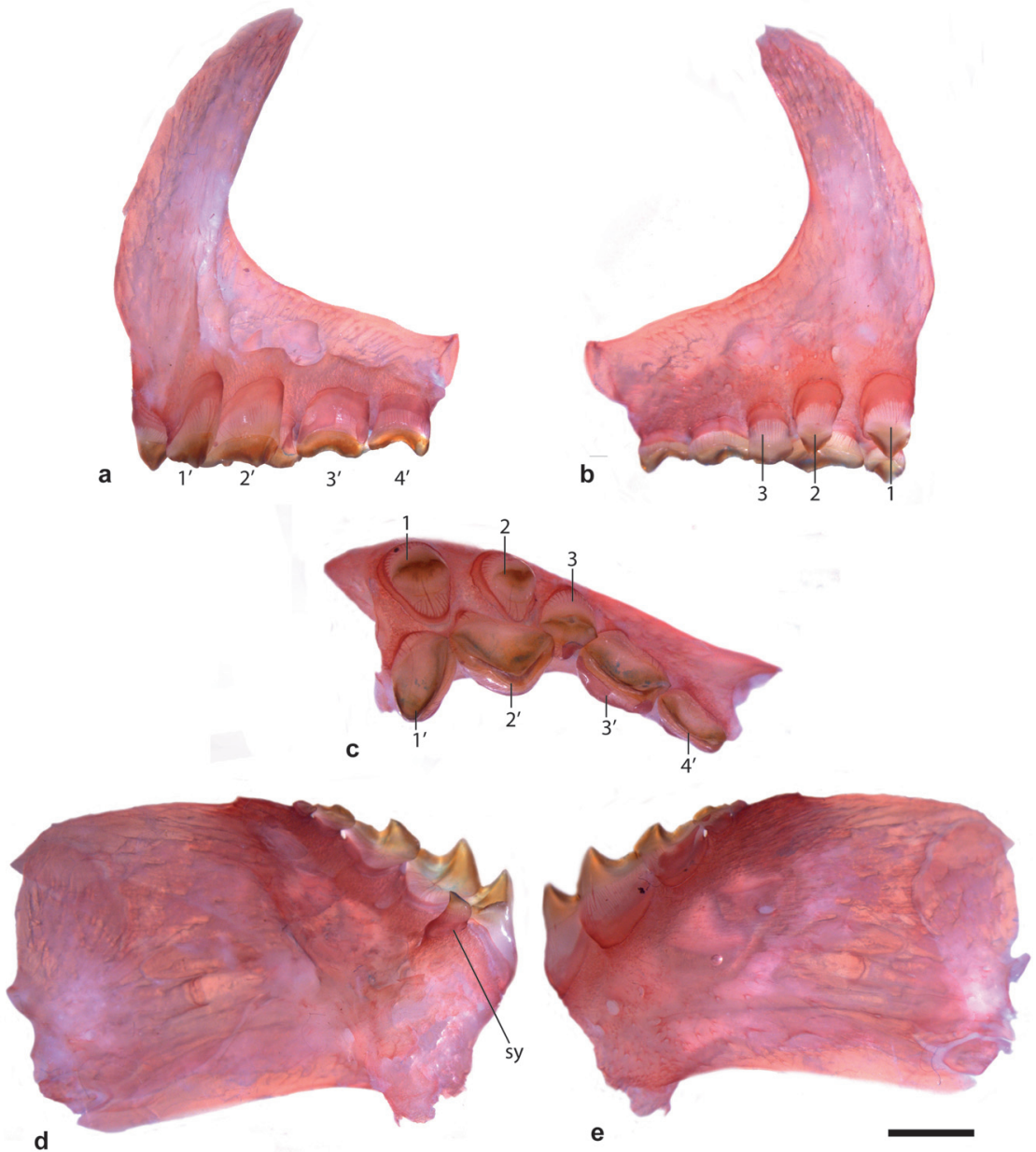

Fig. 2. Utiaritichthys esguiceroi, LIRP 8185, $194.0 \mathrm{~mm}$ SL, paratype. a-c, lingual, labial, and ventral views of left premaxilla (13 teeth in labial row; 1'-4' teeth in lingual row); d-e, lingual and labial views of left dentary. sy = symphyseal tooth. Scale bar $=2 \mathrm{~mm}$.

Color in life. Based on LIRP 8157, 193.0 mm SL. Background body color greenish silver, lightly golden over facial bones. Ventral portion of body white. All fins green; dorsal fin dark green, with hyaline ray tips forming a transparent narrow margin. Anterior anal-fin rays dark, becoming progressively light towards posterior. Anterior borders of pectoral and pelvic fins darker than posterior borders. Caudal-fin lobes and base darker than their respective margins. Iris golden with black dorsal and ventral areas.

Sexual dimorphism. Juveniles specimens lacking secondary sexual characters. Adult specimens (188.0-228.3 $\mathrm{mm} \mathrm{SL}$ ) with distinct secondary sexual characters on analfin. Males specimens with anteriormost nine rays longer than additional rays forming a distinct anterior lobe, and elongation of $11^{\text {th }}$ to $28^{\text {th }}$ branched rays forming second bell-shaped lobe. This condition contrast with that of females in which the anteriormost 12 anal-fin rays are distinctly longer than other posteriormost rays, forming a distinct lobe. It remains unknown at this point whether such modifications are permanent or restricted to reproductive seasons.
Distribution. All Utiaritichthys esguiceroi samples were collected in the upper section of the rio Juruena, Tapajós drainage, upriver of Salto de Utiariti (waterfall), município de Sapezal, Mato Grosso State, Brazil (Fig. 3).

Ecological notes. Esguicero (pers. comm.), based on the examination of the stomach contents of approximately 50 specimens (non-type material), found that juveniles of Utiaritichthys esguiceroi fed on aquatic and terrestrial insects and particulate organic matter, whether the adults fed almost exclusively on Podostemaceae macrophytes and filamentous algae, both typical of riffles and rapids. Furthermore, juveniles inhabit the calm portions of the rio Juruena - usually near the margins-, whereas the adults swim in the main river channel, mostly in riffles and rapids. It is noteworthy that Utiaritichthys esguiceroi diet and mesohabitat preference ontogenetic shifts are similar to the same shifts observed by Jégu et al. (1989) in Mylesinus paraschomburgkii Jégu, Santos \& Ferreira.

Etymology. The specific epithet is named after André L. H. Esguícero, collector of the holotype and paratypes of the new species. 
Remarks. Notwithstanding the unresolved monophyly and taxonomic definition of Utiaritichthys, all the species of Utiaritichthys (including the one described herein) present non-parallel premaxillary teeth rows (see Fig. 2), as already pointed by Jégu et al. (1992) and Géry 1972 - and also lack, as the species presently allocated in Myloplus, the unique characters possessed by the Serrasalminae genus Myleus, Tometes, Mylesinus, and Ossubtus cited by Jégu et al. (1992).

Considering the all problems cited before, our decision to allocate the new species described herein in the genus Utiaritichthys is based on the fact that all our examined specimens share all the Utiaritichthys characters listed in the genus redescription, differing from the Myloplus only by a comparatively longer body (see Jégu et al., 1992). Furthermore, since an unequivocal phylogenetic definition of Myloplus is currently lacking, we believe that is most prudent to allocate the new species in the genus Utiaritichthys.

Specimens of Utiaritichthys esguiceroi and $U$. sennaebragai were both collected in the upper rio Tapajós drainage, although both species seem to be geographically separated by a major waterfall, at least $70 \mathrm{~m}$ high.

Although Utiaritichthys esguiceroi is morphometricallly very similar to Utiaritichthys sp. n. of Jégu et al. (1992: 116, table II) based on a single specimen deposited in the Museum National d'histoire naturelle, Paris (MNHN 1991-704) and collected in Fleuve Sinnamary, Guyana, the absence of mandibular simphyseal teeth, the lower number of perforated scales (83) on the lateral line, and the higher numbers of prepelvic (28) and postpelvic (14) spines, clearly separate Utiaritichthys esguiceroi from that known but undescribed species.

The apparent endemicity of Utiaritichthys esguiceroi, together with the respective endemicities of Jupiaba paranatinga Netto-Ferreira, Zanata, Birindelli \& Sousa, Astyanax ajuricaba Marinho \& Lima and Hyphessobrycon hexastichos Bertaco \& Carvalho reinforces the recommendation of Carvalho \& Albert (2011) to scientifically explore the ichthyofauna of the highly endemic area of the huge upper rio Tapajós basin. This exploration must done very quickly, due to the major and crescent anthropic impacts being inflicted to that area. All the fast flowing water species of the Serrasalmidae representatives (i.e., Acnodon, Mylesinus, Ossubtus, and Utiaritichthys) are most likely seriously threatened by at least ten hydroelectric dams, either in construction, or planned for the upriver and fast flowing sections of the major tributaries of the rio Amazonas right margin (Brasil - MME, 2011), like the rios Madeira, Tapajos, and Xingu (see Jégu et al., 1992; Zuanon \& Jégu, 2008; Vieira et al., 2008). The 50 non-type specimens examined on "Ecological Notes" were dissected for stomach content analysis and, consequently, had their respective visceral cavities emptied, strongly altered body proportions making them unsuitable for taking morphometric data. Nonetheless, no significant differences were found in their meristic and coloration in comparison with type-specimens.

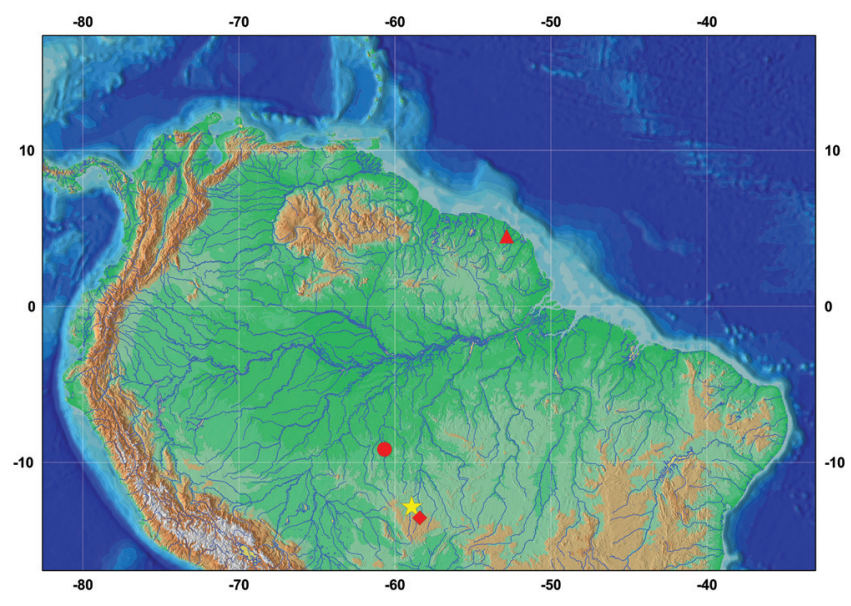

Fig. 3. Map of northern South America, showing the type locality of distribution of Utiaritichthys species. Utiaritichthys esguiceroi (yellow star); Utiaritichthys sennaebragai (red lozenge); Utiaritichthys longidorsalis (red circle); and Utiaritichthys sp. Sinammary (red triangle).

\section{Key of species of genus Utiaritichthys.}

1. Lateral line perforated scales 99-101; 17-19 prepelvic spines; 20-21 postpelvic spines; 23-25 circumpeduncular scales; interdorsal width 11.8-15.6\% SL; and adipose-fin 4.2-5.8\% SL U. esguiceroi (rios Juruena, Tapajós drainage, Amazonas system).

1 '. Lateral line perforated scales 69-83; 9-31 prepelvic spines; 15-19 postpelvic spines; 30-48 circumpeduncular scales; interdorsal width 7.1-7.9\% SL; and adipose-fin 3.7-3.8\% SL

2. Lateral line perforated scales 69-83; 9-13 prepelvic spines; 15-19 postpelvic spines; and 30-48 circumpeduncular scales U. sennaebragai (rios Tapajós, Xingu, Tocantins-Araguaia, Juruena, and Trombetas, rio Amazonas system, and río Orinoco, Venezuela).

2'. Lateral line perforated scales 78-82; 28-31 prepelvic spines; 14 postpelvic spines; and 33-35 circumpeduncular scales .. U. longidorsalis

(rio Aripuanã, rio Madeira drainage, rio Amazonas system).

Comparative material. Utiaritichthys sennaebragai: All from Brazil. MNRJ 12154, 322.0 mm SL, female, lectotype, Mato Grosso, Salto do Utiarity, tributary of rio Papagaio, Tapajós drainage.. MNRJ 3407, 3, 173.0-291.0 mm SL, females, paralectotypes, same locality of lectotype. LIRP 8186, 9, 118.0-205.0 mm SL, Mato Grosso, Sapezal, rio Juruena downstream, Tapajós drainage. LIRP 9041, 8, 44.8-126.2 mm SL, Mato Grosso, Sapezal, rio Juruena, PCH Telegráfica Resgate. LIRP 9042, 1, 149.1 mm SL, Mato Grosso, Sapezal, rio Juruena, PCH Rondon. LIRP 9043, 3, 118.2-135.0 mm SL, Mato Grosso, Sapezal, rio Juruena, PCH Telégrafica. LIRP 9044, 19, 77.4-246.8 mm SL, Mato Grosso, Sapezal, rio Juruena, PCH Telegráfica. MCP 42662, 4, 60.4-142.4 mm SL, Mato Grosso, Sapezal, Tapajós, rio Papagaio. MZUSP 79024, 11, 12.7-121.3 mm SL, Mato Grosso, rio Jaurú, fazenda do Sr. Salú, upriver of Salto da Fumaça. 


\section{Acknowledgments}

Authors are grateful to André Luiz Henríques Esguícero, Marlene Sofia Arcifa Froehlich, and Rodrigo J. Ilário, the collectors of specimens of Utiaritichthys esguiceroi. Paulo Buckup and Marcelo Britto (MNRJ) for loaning comparative material. To Veronica Slobodian for examining type material of $U$. sennaebragai. TNAP was financially supported by Fundação de Amparo à Pesquisa do Estado de São Paulo (FAPESP 2008/52379-5), RMCC is a researcher of Conselho Nacional de Desenvolvimento Científico e Tecnológico do Brasil (CNPq 307554/2010-4). Authors also thank the Programa de Pós-Graduação em Biologia Comparada, FFCLRP/USP for the support. This study was partially supported by the FAPESP Thematic Projects "Phylogenetic relationships in the Characidae (Ostariophysi: Characiformes) (FAPESP 04/092196, RMCC Coordinator and Principal Investigator), and "South America Characiformes” Inventory - SACI” (FAPESP 11/502827), both authors are Associated Investigators.

\section{Literature Cited}

Andrade, M. C., T. Giarrizzo \& M. Jégu. 2014. Tometes camunani (Characiformes: Serrasalmidae), a new species of phytophagous fish from the Guiana Shield, rio Trombetas basin, Brazil. Neotropical Ichthyology, 11: 297-306.

Brasil, Ministério de Minas e Energia, Empresa de Pesquisa Energética. 2011. Plano Decenal de Expansão de Energia 2020, Brasília.

Calcagnotto, D., S. A. Schaefer \& R. DeSalle. 2005. Relationships among characiform fishes inferred from analysis of nuclear and mitochondrial gene sequences. Molecular Phylogenetics and Evolution, 36: 13553.

Carvalho, T. P. \& J. Albert. 2011. The Amazon-Paraguay Divide. Pp. 193-202. In: Albert, J. \& R. E. Reis. (Orgs.). Historical Biogeography of Neotropical Freshwater Fishes. Berkeley, University of California Press.

Cione, A. L., W. M. Dahdul, J. G. Lundberg \& A. Machado-Allison. 2009. Megapiranha paranensis, a new genus and species of Serrasalmidae (Characiformes, Teleostei) from the upper Miocene of Argentina. Journal of Vertebrate Paleontology, 29: 350-358.

Eschmeyer, W.N. \& J.D. Fong. 2014. Species of fishes by family/ subfamily. Online version dated 12 JAN 2012. Electronic Database accessible at <http://research.calacademy.org/research/ ichthyology/catalog/SpeciesByFamily.ap>. Captured on 09 August 2013.

Géry, J. 1972. Poissons characoïdes des Guyanes. I. Généralités. II. Famille des Serrasalmidae. Zoologische Verhandelingen, (Leiden), 122:1-250.

Hubert, N. \& J. F. Renno. 2010. Description of a new Serrasalmus species, Serrasalmus odyssey n. sp. Pp. 52-59. In: Evolution of the neotropical ichthyofauna - molecular and evolutionary perspectives about the origin of the fish communities in the Amazon. VDM Publishing House, Verlag Dr. Müller, Saarbücken, Germany.
Jégu, M. 2003. Subfamily Serrasalminae. Pp. 182-184. In: Reis, R. E., S. O. Kullander \& C. J. Ferraris Jr. (Eds.). Check list of the freshwater fishes of South and Central America. Porto Alegre, Edipucrs, 729p.

Jégu, M., N. Hubert \& E. Belmont-Jégu. 2004. Réhabilitation de Myloplus asterias (Müller \& Troschel, 1844), espèce-type de Myloplus Gill, 1896 et validation du genre Myloplus Gill (Characidae: Serrasalminae). Cybium, 28: 119-157.

Jégu, M., G. M. Santos \& E. Ferreira. 1989. Une nouvelle espèce du genre Mylesinus (Pisces, Serrasalmidae) M. paraschomburgkii, décrite des bassins du Trombetas et du Uatuma (Brésil, Amazonie). Revue d'Hydrobiologie Tropicale, 22: 49-62.

Jégu, M., L. Tito de Morais \& G. Mendes dos Santos. 1992. Redescription des types d'Utiaritichthys sennaebragai MirandaRibeiro, 1937 et description d'une nouvelle espècie du bassin amazonien, $U$. longidorsalis (Characiformes, Serrasalmidae). Cybium, 16: 105-120.

Machado-Allison, A. 1982. Studies on the subfamily Serrasalminae (Teleostei, Characidae): Part 1. Comparative study of the juveniles of the genera Colossoma and Piaractus from Venezuela. Acta Biologica Venezuelana, 11: 1-101.

Machado-Allison, A. 1983. Estudios sobre la sistemática de la subfamília Serrasalminae (Teleostei, Characidae). Parte II. Discussion sobre la condicion monofilética de la subfamília. Acta Biologica Venezuelana, 11: 145-195.

Machado-Allison, A. 1985. Estudios sobre la sistematica de la subfamilia Serrasalminae. Parte 3: sobre el estatus genérico y relaciones filogenéticas de los géneros Pygopristis, Pygocentrus, Pristobrycon y Serrasalmus (Teleostei - Characidae Serrasalminae). Acta Biologica Venezuelana, 12: 19-42.

Machado-Allison, A. 1986. Comparative osteology of the neurocranium and branchicranium in the genera of the Serrasalminae (Teleostei-Characidae). Acta Biologica Venezuelana, 12: 1-75.

Miranda Ribeiro, A. 1937. Considerações preliminaries sobre a Zoogeografia brasílica, IV. O Campo, setembro: 54-59.

Mirande, J. M. 2010. Phylogeny of the family Characidae (Teleostei: Characiformes): from characters to taxonomy. Neotropical Ichthyology, 8: 385-568.

Orti, G., P. Petry, J. I. R. Porto, M. Jégu \& A. Meyer. 1996. Patterns of nucleotide change in mitochondrial ribosomal RNA genes and the phylogeny of piranhas. Journal of Molecular Evolution, 42: 169-182.

Taylor, W. R. \& G. C. Van Dyke. 1985. Revised procedures for staining and clearing small fishes and other vertebrates for bone and cartilage study. Cybium, 9: 107-119.

Vieira, F., R. M. C. Castro \& C. B. M. Alves. 2008. Henochilus wheatlandii. Pp. 68-70. In: Machado, A. B. M., G. M. Drummond \& A. Pereira. (Orgs.). Livro vermelho da fauna brasileira ameaçada de extinção. Belo Horizonte: Ministério do Meio Ambiente.

Zuanon, J. \& M. Jégu. 2008. Ossubtus xinguense. Pp. 87-88. In: Machado, A. B. M., G. M. Drummond \& A. Pereira. (Orgs.). Livro vermelho da fauna brasileira ameaçada de extinção. Belo Horizonte: Ministério do Meio Ambiente.

Submitted August 14, 2013 Accepted May 18, 2014 by Marcelo Britto Published June 30, 2014 